\title{
O INSTITUTO DA FAMÍLIA E A VALORIZAÇÃO DO AFETO COMO PRINCÍPIO NORTEADOR DAS NOVAS ESPÉCIES DA INSTITUIÇÃO NO ORDENAMENTO JURÍDICO BRASILEIRO
}

\begin{abstract}
Roberta Carvalho Vianna'
Resumo: $O$ presente artigo tem como escopo destacar aspectos legais e doutrinários pertinentes ao instituto da família no ordenamento jurídico brasileiro. Serão abordadas de maneira sucinta, as espécies de família previstas na legislação pátria, assim, como também, a influência do afeto como princípio fundamental das novas espécies do instituto.
\end{abstract}

Palavras-chave: Afeto. Direito de Família. Família. Valor.

\section{INTRODUÇÃO}

O direito é a ferramenta essencial à organização da sociedade, é através dele que o Estado intervém para assegurar direitos, deveres e proteção ao indivíduo. Embora o Estado tenha o dever de regulamentar as relações pessoais e o convívio social, não pode deixar de respeitar o direito à liberdade individual de cada cidadão.

No âmbito do direito familiar pode-se afirmar que esta liberdade está um tanto restrita pelo Estado, quando este reconheceu expressamente apenas o matrimônio, a união estável e a família monoparental como espécies de família existentes no ordenamento jurídico pátrio.

1 Bacharel em Direito pela UNIVALI - Universidade do Vale do Itajaí. Aluna da Escola Superior da Magistratura do Estado de Santa Catarina - ESMESC - Florianopolis/SC. E-mail: betavianna@hotmail.com 
Os valores socias se modificam no transcurso do tempo, por óbvio a sociedade também se modifica, logo, essas modificações geram reflexos nas relações pessoais. O direito e a legislação precisam acompanhar estas mudanças para evitar insegurança jurídica à sociedade e ao próprio Estado.

A família atual está vinculada ao elemento que explica sua função, a afetividade. O princípio da afetividade compreende, sobretudo, a evolução do direito tornando-o aplicável a todas as formas de manifestação da família, tendo como premissa uma nova cultura jurídica que possa permitir a proteção e o reconhecimento estatal de todas as entidades familiares, centrando-se no afeto como sua maior preocupação.

Nesta esteira, este artigo científico tem por finalidade demonstrar ao operador do direito, aspectos importantes acerca da instituição familiar, especialmente em relação a valorização do afeto como princípio norteador da entidade familiar, bem como, enfatizar a necessidade do reconhecimento das novas espécies do instituto na legislação patria.

\section{CONCEITO DE FAMÍLIA}

Com a evolução do tempo e com as constantes mudanças sócio-econômicas, o ser humano vai alterando seu estilo de vida e também seus hábitos, desligando-se dos costumes, da tradição e dos conceitos herdados das antigas civilizações.

O conceito de família é bastante variável para a sociedade atual, até porque, este, é vinculado a uma série de princípios éticos, morais e também religiosos.

A Constituição Brasileira de 1988 modificou a conceituação do instituto da família, especialmente quanto à idéia antiga, que conceituava tal estrutura através do poder patriarcal.

Hoje a família não decorre somente do casamento civil e nem é concebida exclusivamente como união duradoura entre homem e mulher. Por força do disposto no parágrafo $4^{\circ}$ do artigo $226 \mathrm{da} \mathrm{CF}$, a família é concebida, na sua noção minima, como a "comunidade formada por qualquer dos pais e 
seus descendentes, abrangendo, também, as outras formas de entidade familiar, como aquela decorrente do casamento civil, do casamento religioso, e da união estável entre o homem e a mulher, nos termos dos outros dispositivos contidos no artigo 226. (MACHADO, 2003, p. 159)

Sobre a entidade familiar leciona Tourino apud Moraes (2004, p. 705):

O conceito de família pode ser analisado sob duas acepções: ampla e restrita. No primeiro sentido, a família é o conjunto de todas as pessoas, ligadas pelos laços do parentesco, com descendência comum, englobando, também, os afins - tios, primos, sobrinhos e outros. É a família distinguida pelo sobrenome: família Santos, Silva, Costa, Guimarães e por aí afora, neste grande país. Esse é o mais amplo sentido da palavra. Na acepção restrita, família abrange os pais e os filhos, um dos pais e os filhos, o homem e a mulher em união estável, ou apenas irmãos (...).

Destarte, para o Direito, família consiste na organização social formada a partir de laços sanguíneos, jurídicos e afetivos.

\section{A IMPORTÂNCIA DO INSTITUTO DA FAMÍLIA COMO FONTE DE FORMAÇÃO DO INDIVÍDUO}

A instituição familiar desempenha papel fundamental na formação da sociedade e do indivíduo, pois é através dela que advém os ensinamentos de cunho ético e moral. Hironaka apud Dias (2010, p. 27) assevera:

Não importa a posição que o indivíduo ocupa na família, ou qual a espécie de agrupamento familiar a que ele pertence - o que importa é pertencer ao seu âmago, é estar naquele idealizado lugar onde é possivel integrar sentimentos, esperanças, valores e se sentir, por isso, a caminho da realização de seu projeto de felicidade. 
Uma família bem sucedida, não é aquela que promove somente conforto material a seus membros, mas sim, aquela que promove amor, carinho, educação, solidariedade e respeito mútuo. Ou seja, é aquela que assegura uma criação digna.

A instituição familiar realiza funções relevantes, lançando valores fundamentais para gerações novas, assim, leciona Oliveira (2002, p. 267):

A primeira função garante à família a transmissão de normas, papéis e valores aos filhos, permitindo a estes sua integração numa sociedade baseada sobre a realização pessoal. A segunda permite aos adultos encontrar, na família e no casamento, seu equilíbrio emocional.

Lima (1960, p. 26 ) complementa:

A família na sociedade destaca-se para o homem como o seu mais importante elo de ligação no relacionamento social, pois é no seio dela que ele surge, recebe a proteção indispensável para a continuidade da vida e se prepara para os embates que o futuro lhe reserva em termos de subsistência, evolução pessoal e material que a humanidade busca sem cessar, como fator de seu desenvolvimento e progresso continuo.

A construção do caráter e da personalidade da criança ou adolescente é responsabiliade do pai e da mãe. Nesse sentido, corrobora Liberati (2007, p. 25):

Os pais são responsáveis pelo desenvolvimento integral de seus filhos. Cabe-lhes, também, sua proteção, não só porque detém o poder familiar, mas pelo dever de garantir-lhes os direitos fundamentais assegurados pelo artigo 227 da CF, tais como a vida, a saúde, a alimentação e a educação.

"A ausência da família, a carência de amor e de afeto comprometem o desenvolvimento da criança e do adolescente. 
A família é, portanto, o agente socializador por excelência do ser humano (LIBERATI, 2007, p. 25)".

O artigo 227 da Constituição Federal de 1988 considera o direito à convivência familiar e comunitária um direito fundamental da criança e do adolescente. Este direito também encontra respaldo no Estatuto da Criança e do Adolescente em seu artigo 19, o qual regulamenta o referido dispositivo constitucional, determinando que toda criança e adolescente tem direito a ser criado e educado no seio de sua família, e, excepcionalmente, em família substituta.

É, portanto, direito essencial de todos, crianças, adolescentes, adultos e idosos, ter uma família. "Esse direito é personalíssimo, intransferível, inalienável e imprescritivel (LIBERATI, 2007, p. 25)".

\section{AS ESPÉCIES DE FAMÍLIA NO ORDENAMENTO JURÍDICO BRASILEIRO}

\subsection{Família Matrimonial}

A família matrimonial é aquela oriunda do casamento. No Código Civil de 1916, a família, como forma de instituição se encontrava vinculada somente através do casamento, o qual assegurava direitos e impunha deveres na esfera pessoal e patrimonial do indivíduo.

O casamento consagra o que a doutrina trata de família matrimonial, onde os indivíduos ingressam por vontade própria, por meio da chancela estatal.

Como uma relação complexa que é, o casamento gera direitos e deveres a ambos os cônjuges, os quais estão disciplinados no artigo 1.566 do CC, são eles:

Art. 1.566. São deveres de ambos os cônjuges:

I - fidelidade recíproca;

II - vida em comum, no domicílio conjugal;

III - mútua assistência; 
IV - sustento, guarda e educação dos filhos;

$\mathrm{V}$ - respeito e consideração mútuos.

Sobre o casamento Souza (2009) destaca duas teorias:

A primeira, aponta ser o casamento o principal vínculo de família. Os adeptos desta corrente apontam que os artigos 226, $\S \S 1^{\circ}$ e $2^{\circ}$ da CF topograficamente privilegiam o casamento. Em verdade, o artigo 226, § 30, da Constituição Federal, ao estabelecer que a lei deverá facilitar a conversão da união estável em casamento, de certa forma, dá o tom da preferência do Constituinte pelo casamento. Por outro turno, a segunda corrente, defendendo o princípio da isonomia entre os vínculos familiares, estabelece ser o casamento apenas uma das formas de família. Fulcra sua tese nos artigos $5^{\circ}$ e 226 da CF, bem como no projeto do Estatuto das Famílias (Projeto n².285/2007).

O casamento por fim, é um contrato solene pelo qual duas pessoas, de sexos diferentes, se unem, sob a promessa recíproca de fidelidade no amor e da mais estreita comunhão de vida (RIZZARDO, 2007, p. 17).

\subsection{Família Monoparental}

A família monoparental é aquela constituída por um dos pais e seus descendentes. Nessa espécie de família vigora o vínculo de parentesco de ascendência e descendência.

A Constituição Federal de 1988 passou a reconhecer, em seu artigo 226, $\S 4$, expressamente a família monoparental como entidade familiar:

Art. 226. A família, base da sociedade, tem especial proteção do Estado.

(...)

§ 40 Entende-se, também, como entidade familiar a comunidade formada por qualquer dos pais e seus descendentes. 
Sobre as entidades familiares denominadas de famílias monoparentais, temos a explicação de Viana (1998, p. 32):

A Constituição Federal limita-se a dizer que reconhece como entidade familiar a comunidade formada por qualquer dos pais e seus descendentes. Não faz qualquer distinção, o que inibe o intérprete. Nesse conceito está inserida qualquer situação em que um adulto seja responsável por um ou vários menores. Isso permite concluir que ela pode ser estabelecida desde sua origem, ou decorre do fim de uma família constituída pelo casamento. Neste diapasão é possível que ela estabeleça porque a mãe teve um filho, mas a paternidade não foi apurada, ou porque houve adoçào, ou pode resultar da separação judicial ou do divórcio. Nessa linha temos a família monoparental formada pelo pai e o filho, ou pela mãe e o filho, sendo que nos exemplos há o vínculo biológico, ou decorre da adoção por mulher ou homem solteiro. Nada impede que o vínculo biológico que une os membros dessa família, não decorra de congresso sexual, mas resulted a procriação artificial. A mãe solteira submete à inseminação artificial, não sabendo quem seja o doador.

Logo, a família monoparental pode resultar de diversas formas, por meio de viuvez, da separação judicial, do divórcio, da extinção de uniões e, também, pela adoção por pessoas solteiras.

\subsection{União Estável}

No entendimento de Rizzardo (2007, p. 891), união estável: "É uma união sem maiores solenidades ou oficialização pelo Estado, não se submetendo a um compromisso ritual e nem se registrando em órgão próprio”.

A Carta Magna de 1988 passou a reconhecer, em seu artigo 226, § 30, expressamente a união estável como entidade familiar: 
Art. 226. A família, base da sociedade, tem especial proteção do Estado.

(...)

§ 3o Para efeito da proteção do Estado, é reconhecida a união estável entre o homem e a mulher como entidade familiar, devendo a lei facilitar sua conversão em casamento.

O Código Civil de 2002, que passou a regular a matéria, preocupou-se em reconhecer a união estável como instituto, trazendo sua definição da seguinte forma:

Art. 1.723. É reconhecida como entidade familiar a união entre homem e mulher, configurada na convivência pública, continua e duradoura e estabelecida com o objetivo de constituição de família.

Rodrigues (2002, p. 287) conceitua união estável como: “(...) união do homem e da mulher fora do matrimônio de caráter estável, mais ou menos prolongada, para o fim da satisfaça sexual, assistência mútua e dos filhos comuns”.

\subsection{Família Substituta}

A família substituta é uma espécie de família que consiste em substituir em caráter temporário ou permanente a família natural da criança, adolescente e até mesmo de adultos (adoção de maiores).

Em oposição à família natural, quando seus membros estão ligados por laços consaguíneos, há a família substituta, que, pelos termos da Lei $n^{\circ}$ 8.069, assim é considerada em relação ao menos que nela ingressa, em geral sem qualquer laço de parentesco biológico com os demais membros. (RIZZARDO, 2007, p. 567).

Conforme o art. 19 do Estatuto da Criança e do Adolescente (Lei no 8.069/90), toda criança ou adolescente tem direito a ser criado e educado no seio de sua família, seja ela biológica ou substituta. 
Nos procedimentos da infância e juventude, a preferência é sempre da mantença do menor junto aos genitores biológicos. Somente apos acompanhamento técnico jurídico verificatório da inexistência de condições dos genitores, inicia-se a colocação em lar substituto.

De acordo com o artigo 28 do Estatuto da Criança e do Adolescente, há três formas para se efetuar a colocação em família substituta: a tutela, a guarda e a adoção.

A tutela é um instituto do direito civil, que se destina a proteção de pessoas menores de 18 anos, e que se concretizam quando ocorre uma das seguintes situações: a) os pais forem falecidos; b) estiverem ausentes ou c) forem destituídos do poder familar, conforme dispõe o art. 1.728 do CC.

Segundo Liberati (2007, p. 35), existem três modalidades de tutela: a) testamentária ${ }^{2}$; b) legítima ${ }^{3}$ e c) dativa ${ }^{4}$.

A guarda é o instituto pelo qual alguém, parente ou não, assume a responsabilidade sobre um menor. Para Venosa (2007, p. 06) a guarda: "é atributo do poder familiar. Por sua vez cinge uma série de direito e deveres".

A guarda envolve certa autoridade ou um poder de controle, na pessoa e na conduta do menor. Além disso, assegura o direito de estabelecer seu domicílio legal, de permitir que permaneça com terceira pessoa, de orientar e impor o comportamento, de restringir as relações sociais, de obrigar a formação escolar e profissional. Enfim, acarreta o dever de desenvolver o espírito e as atitudes sadias

2 Testamentária, se dá quando o pai ou a mãe, por testamento ou documento autêntico, indica quem será o tutor de seus filhos menores (18 anos) que deixa ao morrer. LIBERATI, Wilson Donizeti. Direito da criança e do adolescente. p. 35.

3 Legítima, se dá na falta da testamentária. Inexistindo tutor nomeado pelos pais, a tutela será deferida aos parentes consangüíneos do menor, na ordem citada no art. 1.731 do CC. LIBERATI, Wilson Donizeti. Direito da criança e do adolescente. p. 35.

4 Dativa, decorrente de sentença judicial, em que, na falta de tutor testamentário ou legítimo, ou quando estes forem escusados ou excluídos da tutela, compete ao juiz escolher outro tutor para o órfão. LIBERATI, Wilson Donizeti. Direito da criança e do adolescente. p. 35. 
da criança e do adolescente, incutindo no espírito o sentido do bem, do justo e de perspectivas de se tornar um elemento útil a sociedade. (RIZZARDO, 2007, p. 569).

O guardião ou a pessoa que detém a guarda passa a assumir diversos encargos de natureza educacional, material e moral, visando proporcionar à criança ou ao adolescente uma vida sadia e feliz.

Oliveira apud Venosa (2007, p. 265) leciona que a guarda no ECA possui três modalidades: a provisória ${ }^{5}$, a permanente ${ }^{6}$ e a peculiar?

O Código Civil de 2002 não disciplinou a guarda de crianças e adolescentes conforme as hipóteses do art. 98 do ECA, evidenciou somente a situação dos filhos nas hipóteses de ruptura da sociedade conjugal e união estável. Todavia, reafirmou a responsabilidade parental conjunta e solidária para ambos os pais, também enfatizada no texto constitucional, art. $226 \S 5^{\circ}$.

O instituto da adoção é uma modalidade artificial de filiação pela qual se aceita como filho, de forma voluntária e legal, um estranho no seio familiar.

Sobre o instituto da adoção, oportuno trazer à colação o entendimento de Wald (2000, p. 197):

A adoção é uma ficção jurídica que cria o parentesco civil é um ato jurídico bilateral que gera laços de paternidade e filiação entre pessoas para as quais

5 A guarda provisória $\left(\S 1^{\circ}\right)$ pode ser concedida liminar ou incidentalmente nos processos de adoção, com exceção nas adoções por estrangeiros, que a lei veda expressamente. OLIVEIRA, Leoni Lopes de. apud VENOSA, Sílvio de Salvo. Direito civil: direito de família.p. 265.

6 A guarda permanente é destinada a atender a situação nas quais, por qualquer razão, não se logrou a adoção ou tutela, objetivando, também, regularizar a guarda de fato. OLIVEIRA, Leoni Lopes de. apud VENOSA, Sílvio de Salvo. Direito civil: direito de família. p. 265.

7 A guarda peculiar $\left(\S 2^{\circ}\right)$ é destinada a atender a situações excepcionais ou eventuais, permitindo ao juiz outorgar representação ao guardião para a prática de determinados atos em benefício do menor. OLIVEIRA, Leoni Lopes de. apud VENOSA, Sílvio de Salvo. Direito civil: direito de família. p. 265. 
tal relação inexiste naturalmente. (...) apresenta a adoção com um ato jurídico solene em virtude do qual a vontade dos particulares, com a permissão da lei, cria, entre pessoas naturalmente estranhas uma à outra, relações análogas às oriundas da filiação legítima.

O instituto da adoção sofreu diversas modificações e adaptações na legislação brasileira ao longo dos tempos, especialmente após a promulgação da CRFB/88 e, também, da promulgação do Estatuto da Criança e do Adolescente.

\section{AS NOVAS ESPÉCIES DE FAMÍLIA}

O conceito de família, principalmente em decorrência de mudanças sociais vem evoluindo no ordenamento jurídico pátrio, formando novas modalidades familiares. $\mathrm{O}$ instituto da família deixou de ser visto como uma entidade na qual tinha por objetivo fundamental a procriação e passou a ter como finalidade primordial a realização afetiva.

Hodiernamente, a família é concebida não só por laços de consangüinidade, como também, pelo afeto e solidariedade mútua.

Destarte, passa-se a demonstrar as novas espécies de família baseadas no princípio da afetividade.

\subsection{Família Anaparental}

A família anaparental é aquela baseada no afeto familiar, todavia, sem a presença de pais. "De origem grega, o prefixo "ana” traduz idéia de privação. Por exemplo, "anarquia” significa "sem governo". Esse prefixo me permitiu criar o termo "anaparental” para designar a família sem pais (BARROS, 2003)”.

Família Anaparental é a relação que possui vínculo de parentesco, mas não possui vínculo de ascendência e descendência. A referida espécie de família está disciplinada no artigo 69, caput, do Projeto do Estatuto das Famílias: 
Art. 69. As famílias parentais se constituem entre pessoas com relação de parentesco entre si e decorrem da comunhão de vida instituída com a finalidade de convivência familiar.

A família anaparental é aquela constituída basicamente pela convivência entre parentes dentro de uma mesma estrutura organizacional e psicológica, visando a objetivos comuns, que residem no mesmo lar, pela afetividade que os une ou por necessidades financeiras ou mesmo emocionais, como o medo de viver sozinho.

Como exemplo de família anaparental, podemos destacar: dois irmãos que residam juntos: primos que residam na mesma casa ou, ainda, sobrinhos que residam com tios.

\subsection{Família Pluriparental}

A Família Pluriparental, também denominada de Família Mosaico é uma espécie de entidade familiar que resulta da pluralidade de relações parentais. Conforme o entendimento de Dias (2006, p. 47) esta modalidade familiar surge com o desfazimento de relações incitadas por separação, divórcio, dissolução de união estável ou até mesmo viuvez. O que acontece, é que estas famílias acabam se unindo a outros indivíduos e constituem novas famílias, ou ainda, se unem a outras famílias que também se desmembraram por motivos semelhantes e acabam por criar novos vínculos familiares. Na concepção de Chagas (2007):

Nessa nova organização as famílias passam a receber o "marido da mãe", os filhos do "marido da mãe”, os filhos da nova esposa do pai, as famílias de origem de cada um dos novos pares, cada um trazendo para o núcleo familiar sua própria cultura.

A família pluriparental está definida no artigo 69, § 20 do Projeto do Estatuto das Famílias: 
(...)

$\S 2^{\circ}$ Família pluriparental é a constituída pela convivência entre irmãos, bem como as comunhões afetivas estáveis existentes entre parentes colaterais.

O afeto é fundamental à subsistência desta modalidade familiar, exigindo de seus membros extraordinária capacidade de adaptação e paciência, considerando o fato de serem egressos de famílias anteriores, e, portanto, guardando o conjunto de valores da experiência familiar vivenciada.

Todavia, Dias (2007, p. 47) afirma que a complexidade torna-se ainda mais intensa quando a família mosaico se desfaz para se refazer novamente de forma simultânea, buscando outros pares com seus outros filhos. A partir destas constantes renovações familiares que decorre essa expressiva multiplicidade de parentes afins, desde os pais e filhos até avós, tios, sobrinhos, primos e outros, formando o desenho de um verdadeiro mosaico familiar.

\subsection{Família Eudemonista}

A expressão eudemonista advém da palavra "eudaimonia" de origem grega, a qual significa felicidade. A doutrina eudemonista defende a idéia de que a felicidade é o objetivo primordial da vida humana. Eudemonismo é, conforme Blackburn apud Souza (2009):

Ética baseada na noção aristotélica de "eudaimonia” ou felicidade humana... Embora próxima da "ética da virtude", essa abordagem distingue-se daquele quando é eliminada a identificação grega entre a ação virtuosa e a felicidade. O eudemonismo pode também variar conforme as noções do que é, de fato, a felicidade. Assim, os cirenaicos acentuam o prazer sensual; os estóicos salientam o desapego em relação a bens mundanos, como a riqueza e a amizade. Tomás de Aquino dá mais atenção à felicidade como contemplação eterna de 
Deus e assim por diante.

É um conceito de família que diz respeito à família que busca a realização plena de seus membros, constituindo-se pela comunhão de afeto recíproco, consideração e o respeito mútuo entre seus membros, independente do vínculo biológico. De acordo com Andrade (2008):

Eudemonista é considerada a família decorrente da convivência entre pessoas por laços afetivos e solidariedade mútua, como é o caso de amigos que vivem juntos no mesmo lar, rateando despesas, compartilhando alegrias e tristezas, como se irmãos fossem, razão para qual os juristas entendem por bem considerá-los como formadores de mais de um núcleo familiar.

O vínculo entre os integrantes desta entidade familiar é afetivo e não somente jurídico ou biológico.

A Constituição Federal de 1988 trouxe proteção à família eudemonista por meio de seus princípios afirmadores da dignidade da pessoa humana como fundamento maior. O art. 226, da Carta Magna e seus parágrafos, adotam a concepção eudemonista de família ao prever como entidade familiar não só o matrimônio, mas também a união estável e a família monoparental. Vejamos o referido dispositivo legal:

Art. 226 A Família, base da sociedade, tem especial proteção do Estado.

(...)

§ 3o - Para efeito da proteção do Estado, é reconhecida a união estável entre o homem e a mulher como entidade familiar, devendo a lei facilitar sua conversão em casamento.

$\S 4^{\circ}$. Entende-se, também, como entidade familiar a comunidade formada por qualquer dos pais e seus descendentes.

(...) 
$\S 7 \circ$ Fundado nos princípios da dignidade da pessoa humana e da paternidade responsável, o planejamento familiar é livre decisão do casal, competindo ao Estado propiciar recursos educacionais e científicos para o exercício desse direito, vedada qualquer forma coercitiva por parte de instituições oficiais ou privadas.

$\S 8^{\circ} \mathrm{O}$ Estado assegurará a assistência à família na pessoa de cada um dos que a integram, criando mecanismos para coibir a violência no âmbito de suas relações.

Dias (2006, p. 53) afirma que:

No momento em que o formato hierárquico da família cedeu à sua democratização em que as relações são muito mais de igualdade e de respeito mútuo, e o traço fundamental é a lealdade, não mais existentes razões morais, religiosas, políticas, físicas e naturais que justifiquem a excessive e indevida ingerência do Estado na vida das pessoas.

"A família é identificada pela comunhão de vida, de amor e de afeto no plano da igualdade, da liberdade, da solidariedade e da responsabilidade recíproca”. (LÔBO, 2002, p.138).

\subsection{Família Homoafetiva}

A união de pessoas do mesmo sexo existe e está presente nos meios sociais e é reconhecida, embora sem legislação.

No Brasil, no aspecto jurídico, a união entre pessoas do mesmo sexo não foi contemplada na legislação. A Constituição Pátria de 1988 não a considerou como família, e nem tampouco a lei civil a regulamentou. No entanto, a jurisprudência vem consolidando o reconhecimento desta união e decidindo sobre seus efeitos. Sobre o tema, leciona Dias (2000, p. 05-13):

Não se diferencia mais a família pela ocorrência do casamento. Também a existência de prole não é essencial para que a convivência mereça reconhe- 
cimento e proteção constitucional (...) se prole ou capacidade procriativa não são essenciais para que a convivência de duas pessoas mereça a proteção legal, não se justifica ter a Constituição deixado de abrigar, sob o conceito de família, a convivência entre pessoas do mesmo sexo, uma vez que a própria lei não permite qualquer distinção em razão do sexo.

Neste diapasão, complementa Guimarães apud Brito (2000, p. 52-53):

(...) Entre princípios fundamentais que regem a sociedade brasileira, contida nos primeiros artigos da Constituição Federal, estão as normas que protegem a dignidade da pessoa humana, a busca de uma sociedade livre, justa e solidária, a erradicação da marginalização dos indivíduos e a promoção do bem estar de todos, sem preconceitos de origem, raça, sexo, cor, idade e quaisquer outras formas de discriminação.

O não reconhecimento da união homossexual como entidade familiar evidencia discriminação, além de ferir princípios constitucionais como o da igualdade e dignidade da pessoa humana. Para Brito (2000, p. 67): “(...) a escolha é um direito constitucional de qualquer cidadão, enquanto o preconceito, além de abominável, é um crime”.

Para Rizzardo (2007, p. 929) a polêmica que paira sobre o tema é delimitada pelos valores morais, pela importância sociológica e pelas matizes psicológicas que desencadeiam tal união perante a sociedade, e que na realidade não tem de fato relevância jurídica.

A omissão de previsão legal sobre união homossexual na legislação brasileira há de ser reavaliada, uma vez que tal união já faz parte da realidade social atual, e não cabe a sociedade e nem tampouco ao Estado discriminar ou interferir na opção sexual dos indivíduos, assim prejudicando a felicidade de cada um. 


\section{O AFETO COMO VALOR JURÍDICO E CAUSA FUNDAMENTAL PARA O RECONHECIMENTO DAS NOVAS ESPÉCIES DE FAMÍLIA}

O transcurso do tempo e as alterções sociais geraram mudanças na esfera jurídica, repercutindo também, no Direito de Família, mais especificamente na família, em relação a sua constituição e função.

Hodiernamente, o afeto é o princípio que norteia as relações familiares. Na concepção de Dias (2010, p. 10) afeto é:

Envolvimento emocional que subtrai um relacionamento do âmbito do direito obrigacional - cujo núcleo é a vontade - e o conduz para o direito das famílias, cujo elemento estruturante é o sentimento de amor, o elo afetivo que funde as almas e confunde patrimônios, fazendo gerar responsabilidades e comprometimentos mútuos.

afeto, enquanto característica inata dos seres humanos, mais do que uma garantia constitucional, é um direito natural do homem:

O direito ao afeto é a liberdade de afeiçoar-se um indivíduo a outro. $\mathrm{O}$ afeto ou afeição constitui, pois, um direito individual: uma liberdade, que o Estado deve assegurar a cada indivíduo, sem discriminações, senão as mínimas necessárias ao bem comum de todos. (BARROS, 2002).

"O afeto transcende a própria família. Não é um laço que une apenas os integrantes de um núcleo familiar, não é apenas um valor jurídico, mas um sentimento que nutre relações (...). (BARROS apud DIAS, 2009, p. 70).

Na concepção de Lôbo (2003, p. 56) a afetividade não resulta do sangue e nem da biologia. Tanto o afeto quanto a solidariedade resultam da convivência familiar.

$\mathrm{Na}$ transformação da família e de seu Direito, o transcurso apanha uma 'comunidade de sangue' e celebra, ao final deste século, a possibilidade de uma 
'comunidade de afeto'. Novos modos de definir o próprio Direito de Família. Direito esse não imune à família como refúgio afetivo, centro de intercâmbio pessoal e emanador da felicidade possível (...). Comunhão que valoriza o afeto, afeição que recoloca novo sangue para correr nas veias do renovado parentesco, informado pela substância de sua própria razão de ser e não apenas pelos vínculos formais ou consangüíneos. Tolerância que compreende o convívio de identidades, espectro cultural, sem supremacia desmedida, sem diferenças discriminatórias, sem aniquilamentos. Tolerância que supõe possibilidade e limites. Um tripé que, feito desenho, pode-se mostrar apto a abrir portas e escancarar novas questões. Eis, então, o direito ao refúgio afetivo. (FACHIN, 2003, p. 317-318).

Neste mesmo norte, acrescenta Dias (2009, p. 55):

A família identifica-se pela comunhão de vida, de amor, de afeto no plano da igualdade, da liberdade, da solidariedade e da responsabilidade recíproca. No momento em que o formato hierárquico da família cedeu à sua democratização, em que as relações são muito mais de igualdade e de respeito mútuo, e o traço fundamental é a lealdade, não mais existem razões morais, religiosas, políticas, físicas ou naturais que justifiquem a excessiva e indevida ingerência do Estado na vida das pessoas.

Embora a palavra afeto não esteja expressamente presente no texto constitucional, a mesma encontra-se de maneira implícita na legislação pátria, conforme leciona Dias (2009, p. 69):

(...) ao serem reconhecidas como entidade familiar merecedora da tutela jurídica as uniões estáveis, que se constituem sem o selo do casamento, tal significa que o afeto, que une e enlaça duas pessoas, adquiriu reconhecimento e inserção no sistema jurídico. Houve a constitucionalização de um modelo de família eudemonista e igualitário, com maior espaço para o afeto e a realização individual. 
Da mesma forma é a lição de Pereira (2002, p. 230):

(...) para quem relativizar o casamento, permitindo sua dissolução, bem como o equiparar às uniões estáveis, que não exigem qualquer formalidade significa, em última análise, a compreensão de que o verdadeiro casamento se sustenta no afeto, não nas reminiscências cartoriais. $O$ Direito deve proteger a essência, muito mais do que a forma ou a formalidade.

O Código Civil, também não utiliza expressamente a palavra afeto, no entanto, é possível vislumbrar à existência fundamental deste princípio em vários de seus artigos, como por exemplo o art. 1.584 , parágrafo $5^{\circ}$, o qual trata da situação de guarda do(s) filho(s) no caso de separação dos pais. Vejamos o referido dispositivo legal:

Art. 1.584 A guarda, unilateral ou compartilhada, poderá ser:

(...)

$\S 5$ Se o juiz verificar que o filho não deve permanecer sob a guarda do pai ou da mãe, deferirá a guarda à pessoa que revele compatibilidade com a natureza da medida, considerados, de preferência, o grau de parentesco e as relações de afinidade e afetividade. (grifou-se)

O reconhecimento do valor jurídico do afeto permite admitir efetivamente seus efeitos sobre a legislação civil. A esse respeito, pontifica Dias (2007, p. 68):

a) Ao estabelecer a comunhão plena de vida no casamento (CC, art. 1.511);

b) Quando admite outra origem à filiação além do parentesco natural e civil (CC, art. 1.593);

c) $\mathrm{Na}$ consagração da igualdade na filiação (CC, art. 1.596); 
d) Ao fixar a irrevogabilidade da filiação (CC, art. 1.604);

e) Quando trata do casamento e dissolução (CC, arts. 1.511 e seguintes; 1.571 e seguintes), fala antes das questões pessoais do que dos seus aspectos patrimoniais.

A Constituição Federal de 1988 passou a garantir o mesmo tratamento e os mesmos direitos entre filhos adotivos e filhos consanguíneos. Neste contexto, é possível afirmar que o afeto obteve valorização jurídica na Carta Magna em virtude da extinção da distinção entre os filhos. Cumpre-se ressaltar, que a intenção do legislador nesta equivalência de direitos foi mais do que perfeita ao instituto da adoção, vez que este é o instituto jurídico que pressupõe afeto. Villela (1980, p. 45) compartilha: "(...) a paternidade reside antes no serviço e no amor do que na procriação”.

Comentando, ainda, sobre o instituto da adoção e a afetividade, vale trazer à colação o entendimento de Dias (2007): “(...) é de tal ordem a relevância que se empresta ao afeto que se pode dizer agora que a filiação se define não pela verdade biológica, nem a verdade legal ou a verdade jurídica, mas pela verdade do coração".

A parentalidade socioafetiva está ganhando destaque nos Tribunais pátrios, tanto que foi objeto de enunciados na I e III Jornada de Direito Civil, promovida pelo Conselho da Justiça Federal, sob a chancela do Superior Tribunal de Justiça, que não apenas reconheceu a instituição da parentalidade socioafetiva, como também demonstrou o valor do afeto no ordenamento jurídico brasileiro, como se verifica a seguir:

Enunciado $n^{\circ}$ 103, do Conselho da Justiça Federal, aprovado na I Jornada de Direito Civil: o Código Civil reconhece, no art. 1.593, outras espécies de parentesco civil além daquele decorrente da adoção, acolhendo, assim, a noção de que há também parentesco civil no vínculo parental proveniente quer das técnicas de reprodução assis- 
tida heteróloga relativamente ao pai (ou mãe) que não contribuiu com seu material fecundante, quer da paternidade socioafetiva, fundada na posse do estado de filho.

(...)

Enunciado n 108, do Conselho da Justiça Federal, aprovado na I Jornada de Direito Civil: no fato jurídico do nascimento, mencionado no art. 1.603, compreende-se à luz do disposto no art. 1.593, a filiação consangüínea e também a socioafetiva.

(...)

Enunciado no 256, do Conselho da Justiça Federal, aprovado na III Jornada de Direito Civil: a posse de estado de filho (parentalidade socioafetiva) constitui modalidade de parentesco civil.

No que tange à Lei Maria da Penha (Lei n $\left.{ }^{\circ} 11.340 / 2006\right)$ a qual regula a Violência contra a Mulher, o afeto está inserido no art. $5^{\circ}$, III, vejamos:

Art. 5 Para os efeitos desta Lei, configura violência doméstica e familiar contra a mulher qualquer ação ou omissão baseada no gênero que lhe cause morte, lesão, sofrimento físico, sexual ou psicológico e dano moral ou patrimonial:

\section{(...)}

III - em qualquer relação íntima de afeto, na qual o agressor conviva ou tenha convivido com a ofendida, independentemente de coabitação.”

Por fim, a afetividade como princípio fundamental pode ser encontrada no Projeto de Lei no $2285 / 2007^{8}$, o qual têm por

8 O Projeto de Lei $n^{\circ}$ 2285/2007, de autoria do deputado Sérgio Barradas Carneiro, teve iniciativa do IBDFAM - Instituto Brasileiro de Direito de Família e ficou conhecido como Estatuto das Famílias. O presente Projeto de Lei consolida a legislação de Direito de Família num único documento (retirando do Código Civil o Livro IV, que trata do Direito de Família, e transformando-o numa legislação específica). Recentemente aprovado (15/12/2010) pela Comissão de Constituição, Justiça e Cidadania (CCJ) da Câmara dos Deputados, em caráter conclusivo e aguarda votação no Senado. 
objetivo instituir o "Estatuto das Famílias". Vejamos o artigo 50 do mencionado projeto:

Art. $5^{\circ}$ Constituem princípios fundamentais para a interpretação e aplicação deste Estatuto a dignidade da pessoa humana, a solidariedade familiar, a igualdade de gêneros, de filhos e das entidades familiares, a convivência familiar, o melhor interesse da criança e do adolescente e a afetividade. (grifou-se)

Verifica-se que o afeto é mais do que um elemento nas relações familiares hodiernas, ele é o valor primordial inerente à estas relações e deve ser encarado como um princípio que regula todo o direito de família.

\section{CONCLUSÃO}

O direito evolui de acordo com as transformações vivenciadas pela sociedade, assim, é possível afirmar que o mesmo também ocorre entre as relações familiares.

É cediço que a entidade familiar não está mais vinculada somente aos liames biológicos. Hoje, as relações de consangüinidade, não são mais importantes do que as oriundas de laços de afetividade e convivência.

A família parte de princípios básicos como a igualdade, solidariedade e responsabilidade recíprocas, e também, é identificada pela comunhão de vida, amor e afeto.

A função básica da família atual caracteriza-se na realização pessoal em relação à afetividade e à dignidade humana, e principalmente, na busca da felicidade. A antiga concepção de família que era preferencialmente procracional desapareceu, ou, pode-se dizer que assumiu caráter secundário.

Com base nos estudos realizados para confecção do presente artigo científico, é possível constatar a necessidade de um regramento formal que tutele as novas espécies de família, pois, embora desprovidas de proteção legal, estas encontram-se 
cada vez mais presentes a apreciação dos Tribunais, como por exemplo, a união homoafetiva.

A ausência de disposições legais atinentes a determinadas matérias não deve servir de justificativa para a disseminação de tratamentos que infrinjam o principio da dignidade da pessoa humana, consagrado na Constituição Federal, especialmente, quando a matéria versa sobre relações pessoais de caráter afetivo/familiar.

$\mathrm{O}$ afeto é digno de tutela porque responde fielmente àquilo que se observa na sociedade. Fingir que não existem famílias que não correspondem à estrutura consignada na Lei é restringir o direito a todos que dele precisam, ou melhor, é transformar as relações sociais em algo mínimo, perfazendo-se tal conduta em um ato claro de inconstitucionalidade, pois o afeto é intrínseco ao homem, e desconsiderá-lo é violar sua dignidade.

Ademais, o afeto além de ser o elemento primordial para a constituição de uma família, é também o valor fundamental para que esta permaneça unida, pois inexiste razão para manutenção de uma estrutura familiar meramente formal e vazia de sentimentos.

\begin{abstract}
The scope of this article is to highlight legal aspects pertinent to de doctrinal and Family Institute in the Brazilian legal system. Will be addressed in a succinct manner, the species of the family home under the law, so also, the influence of affect as a fundamental principle of the new species of the institute.
\end{abstract}

Keywords: Affection. Family Law. Family. Value. 


\section{REFERÊNCIAS}

ANDRADE, Camila. O que se entende por familia eudemonista? Artigonal. Diretório de Artigos Gratuitos. 03 out. 2008. Disponível em: <http:// www.jusbrasil.com.br/noticias/117577/o-que-se-entende-por-familia eudemonista-camila-andrade>. Acesso em: 04 out. 2011.

BARROS, Sérgio Resende de. Direitos humanos da família: principiais e operacionais. 03 dez. 2003. Disponível em: <http://www.srbarros.com.br/ pt/direitos-humanos-da-familia-principiais-e-operacionais.cont $>$. Acesso em: 16 fev. 2011.

BARROS, Sérgio Resende de. O direito a a afeto. Instituto Brasileiro de Direito de Família. 24 jun. 2002. Disponível em: <http://www.ibdfam.org. br/?artigos\&artigo=50>. Acesso em: 25 fev. 2010.

BRASIL. Código Civil. Lei no 3.071, de 01 de janeiro de 1916.

BRASIL. Constituição da República Federativa do Brasil de 1988.

BRASIL. Lei no 8.069, de 13 de julho de 1990. Estatuto da Criança e do Adolescente.

BRASIL. Lei no 10.406 , de 10 de janeiro de 2002. Novo Código Civil.

BRITO, Fernanda de Almeida. União afetiva entre homossexuais e seus aspectos jurídicos. São Paulo: LTr, 2000.

CARNEIRO, Sérgio Barradas; PEREIRA, Rodrigo da Cunha. IBDFAM protocola Estatuto das Famílias em setembro no Congresso Nacional. Revista Jus Vigilantibus. Disponível em: < http://jusvi.com/noticias/27927>. Acesso em: 06 mar. 2011.

CHAGAS, Lunalva Fiúza. Família Mosaico. Integral - Escolas Inteligentes. 24 set. 2007. Disponível em: <http://www.ciadaescola.com.br/artigos/ resultado.asp?categoria $=43 \&$ codigo=206>. Acesso em: 05 fev. 2011.

CONSELHO DA JUSTIÇA FEDERAL. Enunciados. Disponível em: <http://www.cjf.gov.br/revista/enunciados >. Acesso em: 28 fev. 2010.

DIAS, Maria Berenice. Adoção e a espera do amor. LFG - Rede de Ensino Luiz Flávio Gomes. 15 dez. 2007. Disponível em: http://www.lfg.com.br/ public_html/article.php?story $=20071214145743212 \&$ mode $=$ print $>$. Acesso em: 27 fev. 2010. 
DIAS, Maria Berenice et al. Direito de família e o novo código civil. 4. ed. 2a tiragem. Belo Horizonte: Del Rey, 2006.

DIAS, Maria Berenice. Manual de direito das famílias. 3. ed. São Paulo: Revista dos Tribunais, 2006.

DIAS, Maria Berenice. Manual de direito das famílias. 4. ed. São Paulo: Revista dos Tribunais, 2007.

DIAS, Maria Berenice. Manual de direito das famílias. 5. ed. São Paulo: Revista dos Tribunais, 2009.

DIAS, Maria Berenice. Manual de direito das famílias. 6. ed. São Paulo: Revista dos Tribunais, 2010.

DIAS, Maria Berenice. União homossexual - aspectos sociais e jurídicos. Revista Brasileira de direito de família. Porto Alegre, N.4. V.1, jan/mar 2000.

DINIZ, Maria Helena. Curso de direito civil brasileiro. V. 5. São Paulo: Saraiva, 2002.

FACHIN, Luiz Edson. Elementos críticos à luz do novo Código Civil. 2. ed. Rio de Janeiro: Renovar, 2003.

IBDFAM. Estatuto das famílias - justificativa. Instituto Brasileiro de Direito de Família. 31 de out. 2007. Disponível em: < http://www.ibdfam.org. br/?artigos\&artigo=338>. Acesso em: 06 mar. 2011.

LIBERATI, Wilson Donizeti. Direito da criança e do adolescente. 2. ed. São Paulo: Rideel, 2007.

LIMA, Alceu Amoroso. A família no mundo moderno. Rio de Janeiro: Agir Editora, 1960.

LÔBO, Paulo Luiz Netto. Entidades familiares constitucionalizadas: pra além do numerus clausus. Belo Horizonte: Del Rey, 2002.

LÔBO, Paulo Luiz Netto. Código Civil Comentado. Direito de família, relações de parentesco, direito patrimonial. V. 6. São Paulo: Atlas: 2003.

MACHADO, Martha de Toledo. A proteção constitucional de crianças e adolescentes e os direitos humanos. Barueri: Manole, 2003.

MORAES, Alexandre de. Direito Constitucional. 15. ed. São Paulo: Atlas, 2004. 
OLIVEIRA, José Sebastião de. Fundamentos constitucionais do direito de família. São Paulo: Revista dos Tribunais, 2002.

PEREIRA, Rodrigo da Cunha. 2002. Da união estável. ; DIAS, M. B.; (Coord.). Direito de Família e o novo Código Civil. 2. ed. Belo Horizonte: Del Rey, 2002.

RIZZARDO, Arnaldo. Direito de Família: Lei 10.406, de 10.01.2002. 7. ed. Rio de Janeiro: Forense, 2007.

RODRIGUES, Sílvio. Direito Civil: direito de família. 27. ed. São Paulo: Saraiva, 2002.

SOUZA, Daniel Barbosa Lima Faria Corrêa de. Famílias plurais ou espécies de famílias. 29 abr. 2009. Revista Jus Vigilantibus. Disponível em: <http:// jusvi.com/artigos/39460/1>. Acesso em: 15 fev. 2011.

VENOSA, Sílvio de Salvo. Direito Civil: Direito de Família. V. 6. 7. ed. São Paulo: Atlas, 2007.

VIANA, Marco Aurélio da Silva. Curso de direito civil: direito de família. V. 2. 2. ed. revista e atualizada. Belo Horizonte: Del Rey, 1998.

VILLELA, João Baptista. Desbiologização da paternidade. Revista Forense, Rio de Janeiro, V. 71, 1980.

WALD, Arnoldo. O novo direito de família. 13 ed. São Paulo: Saraiva, 2000. 